\title{
Volume 8 Number 2
}

June 1981

0305-0009
Journal of
Child Language

\section{Cambridge University Press}


Editor David Crystal

Associate Editors M. A. G. GARMAN and P. J. Fletcher

\section{Reading Committee}

W. Baker (Edmonton), M. Bowerman (Kansas), C. Cazden (Harvard), E. Clark (Stanford),

M. Donaldson (Edinburgh), J. Dore (New York), S. Ervin-Tripp (Berkeley),

D. Ingram (Vancouver), A. Karmiloff-Smith (Geneva), Y. Lebrun (Brussels),

P. Menyuk (Boston), E. Oksaar (Hamburg), C. Snow (Harvard).

\section{Advisory Board}

U. Bellugi (Salk Institute), M. Braine (New York), C. Ferguson (Stanford),

W. Kaper (Amsterdam), D. McNeill (Chicago), M. Mikes (Novi Sad),

D. Parisi (Rome), J. Prücha (Prague), W. Von Raffler Engel (Nashville),

V. Rúke-Dravina (Stockholm), I. M. Schlesinger (Jerusalem), H. Sinclair

(Geneva), D. Slobin (Berkeley), A. W. Staats (Honolulu). The Secretary of the

International Association for the Study of Child Language.

EDITORIAL POLICY. The journal publishes material on all aspects of the scientific study of language behaviour in children and the principles which underlie it. This includes both normal and pathological development, and the study of both monolingual and multilingual children. Articles may report findings from naturalistic observation, experimental techniques, therapy or educational settings; and the subject-matter may include sounds, grammar, lexicon, semantics, dialect variation, language use, or any other recognized facet of language study. Articles may be limited to the investigation of one language, or they may be comparative studies; focused on individuals, or presenting statistical treatments of groups. Studies of reading, writing, and the use of sign language are included if they are related to general questions of language development; as are articles with a therapy or remedial education bias. Collections of data are acceptable if they are accompanied by adequate interpretive discussion. (Notes for contributors are given on the inside back cover.)

(C) Cambridge University Press $198 \mathrm{I}$

COPYING. This journal is registered with the Copyright Clearance Center, 21 Congress Street, Salem, Mass. or 970. Organizations in the U.S.A. who are also registered with C.C.C. may therefore copy material (beyond the limits permitted by sections 107 and 108 of U.S. copyright law) subject to payment to C.C.C. of the per-copy fee of $\$ 02.00$. This consent does not extend to multiple copying for promotional or commercial purposes. Code $0305-0009 / 8 \mathrm{r} / 2828-0001 \$ 02.00$.

ISI Tear Service, 350 I Market Street, Philadelphia, Pennsylvania 19104, U.S.A., is authorized to supply single copies of separate articles for private use only.

For all other use, permission should be sought from the Cambridge or or New York offices of the Cambridge University Press.

SUBSCRIPTIONS. Fournal of Child Language is published three times a year, in February, June and October; three parts form a volume. The subscription price of Volume 8, $198 \mathrm{I}$, is $£ 29.00$ net (US $\$ 65.00$ ) in the USA and

Canada for institutions $£_{15} .00$ net (US $\$ 29.50$ ) for individuals, including postage.

Single parts cost $£_{11}$.50 each (US $\$_{26} 600$ in the USA and Canada), plus postage.

Orders, which must be accompanied by payment, should be sent

to a bookseller or subscription agent or direct to Cambridge University Press,

The Edinburgh Building, Shaftesbury Road, Cambridge CB2 2 RU (in the USA and Canada, to Cambridge University Press, 32 East 57th Street, New York, N.Y.10022). Copies of the Journal for subscribers in the USA and Canada are sent by air to New York to arrive with minimum delay. Claims for missing issues should be made immediately after receipt of the subsequent issue of the Journal.

ADVERTISING. Enquiries about advertising in the Journal should be sent to the publishers. 